\title{
The Analysis of Generic Science Skills of High School Students
}

\author{
Elok Norma Khabibah ${ }^{1}$, Mohammad Masykuri ${ }^{1}$, Maridi $^{1}$ \\ ${ }^{1}$ Master Program of Science Education, Sebelas Maret University.
}

\begin{abstract}
The success of increasing students' understanding in science can be measured by the students' basic ability while they are in the learning process. This basic ability is known as generic science skills. Generic science skills are the combination between science knowledge and skills. The purpose of this study is to analyze the generic science skills of high school students. This study was conducted at one of the State Madrasah Aliyah in Surakarta academic year 2016/2017. The objects of this study were 81 students of $11^{\text {th }}$ grades in State Madrasah Aliyah 1 Surakarta. This study used descriptive quantitative design. The data were obtained through generic science skills test that contains of generic science skills' indicators. The generic science skills' indicators are direct and indirect observations, scale awareness, symbolic language, logical framework, logical consistency, causality, mathematical modeling, concept constructing, and abstraction. The result of study shows that the generic science skills of high school students get score $53.43 \%$ and it is still low.
\end{abstract}

\section{Keywords: generic science skills; high school students}

\section{INTRODUCTION}

Science and technology in the $21^{\text {st }}$ century has brought people into a very tough global competition era. Therefore, it requires learning that can train students to be ready to face challenges in the future. The results of PISA 2015 show the students' science skills in Indonesia are in the order of $62^{\text {th }}$ out of 70 countries [1]. The data result of ACPD Indonesia [2], TIMSS 2015 also shows that Indonesia students' science skills ranked $45^{\text {th }}$ out of 48 countries. The low quality of science competence of students in Indonesia shows that the learning in school has not been maximized. The success of increasing understanding of students' science can be measured from the basic ability of students while they are in the learning process [3]. This basic ability is known as generic science skills. Generic science skills are intellectual abilities which are resulting from the combination or complex interaction between science knowledge and skills [4]. Generic science skills grow with the development of knowledge and skills within disciplinary areas of various sciences [5]. 
The role of generic science skills is very important in supporting learning, especially in science learning because it can give emphasis to aspects of the process [6]. The learning model use generic science skills make students become active in the learning process on physics lessons. The students are required prepare themselves mentally and for understanding the material information studied on the learning activity. The knowledge with the mental a connection has been produced from the concept formulation by the active students in the learning process [7]. The purpose of science learning as a process that is to improve students' thinking skills, so that students are not only capable and skilled in the field of psychomotor, but also able to think systematically, objectively, and creatively. As revealed by the National Research Council [8] that future skill needs are generic science skills. Generic skills in learning can prepare students for many future situations [5]. The trained and adopting the generic skills component of science in the learning process will make students have life skills for the present and future [9].

The students' skills in science field are the one of the keys to success in adjusting to the changes and readiness to enter the world of technology [10]. The generic science skills relate to the relevance of skills and knowledge to the world of work and life in general, emphasize the role of graduate students as global citizens and communities [11]. The importance of incorporating $21^{\text {st }}$ century thinking skills into the learning process and generic science skills can bring about $21^{\text {st }}$ century thinking skills [12]. The generic science skills are an important skill in life, especially in today's era of globalization [13]. Therefore, an analysis of the generic skills of science at students in Indonesia is required to do to know how good the students have generic science skills.

\section{METHOD}

This study used descriptive quantitative design. The study was conducted in State Madrasah Aliyah 1 Surakarta academic year 2016/2017. The objects of this study were 81 students of $11^{\text {th }}$ grades in State Madrasah Aliyah 1 Surakarta. The data were obtained through generic science skills test that contains of generic science skills indicators. Generic science skill test was adapted and developed from Nature of Science Literacy Test (NOSLiT) by Wenning. It consists of 20 multiple choice questions. It involves questions assessing generic science skills indicators that conducted ten indicators [14] [15]. There are direct and indirect observations, scale awareness, symbolic language, logical framework, logical consistency, casualty, mathematical modeling, concept constructing, and abstraction. Validity of the test got score 0.75 which means the content of validity was good by using the Gregory formula. Therefore, the test was interpreted as valid and it was implemented to those 81 students. For the evaluation of scientific generic skills test, correct and wrong answers have been scored as 1 and 0 respectively. The quality of the test result was determined by the average percentage score obtained by each generic science skills' indicators. The interpretation of high school students' generic science skills quality was shown in Table I. 
TABLE I.CRITERIA OF GENERIC SCIENCE SKILL'S ANALYSIS RESULT INTERPRETATION

\begin{tabular}{cc}
\hline Score Range & Category \\
\hline $0 \%-20 \%$ & Poor \\
$21 \%-40 \%$ & Fair \\
$41 \%-60 \%$ & Moderate \\
$61 \%-80 \%$ & Good \\
$81 \%-100 \%$ & Very good \\
\hline
\end{tabular}

The analysis score result of generic science skills at high school student $\geq 61 \%$ indicates good result.

\section{RESULT AND DISCUSSION}

\section{Result}

The score of generic science skills at high school students are presented in Figure 1 below.

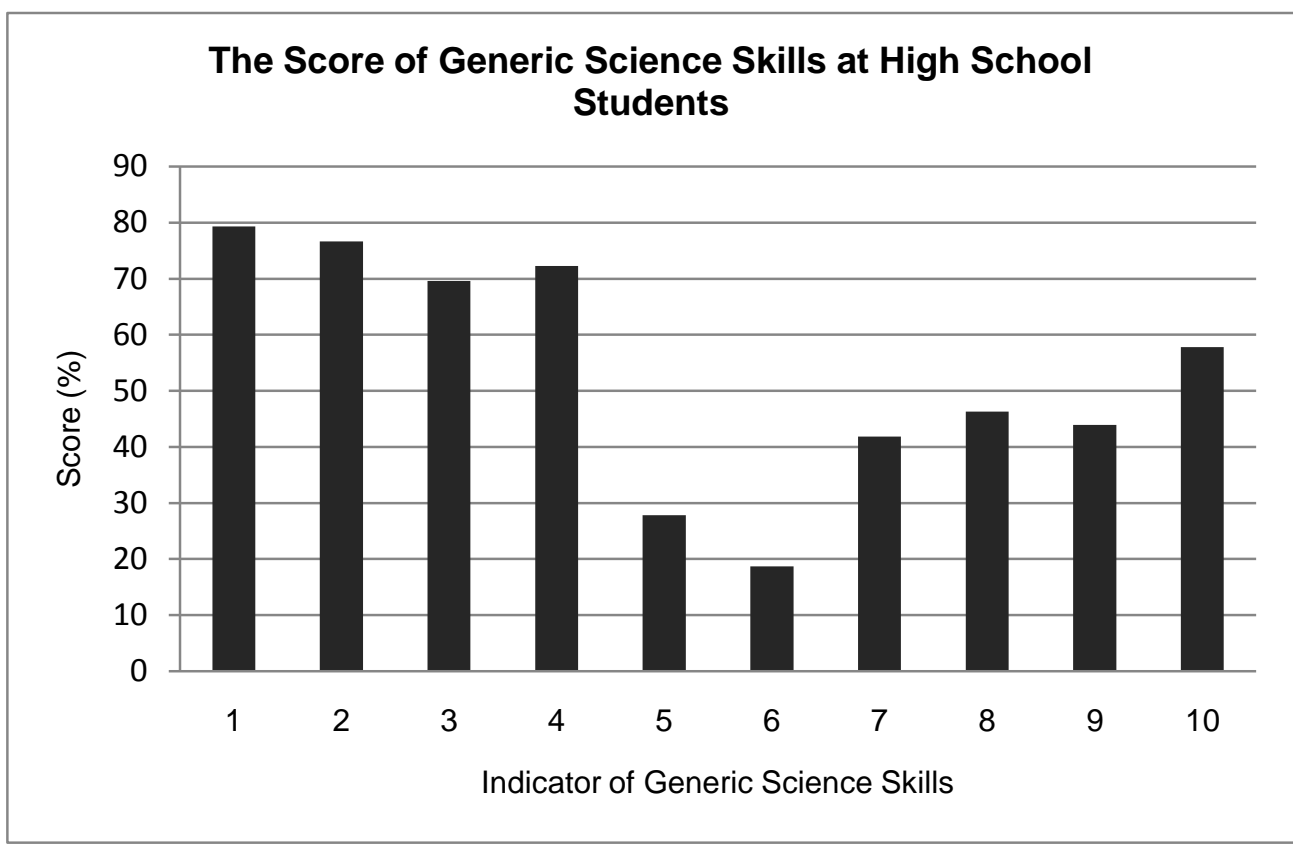

Figure 1. The Score of Generic Science Skills at High School Students

Note:

1 = Direct observation

2 = Indirect observation

3 = Scale awareness

4 = Symbolic language

5 = Logical framework
6 = Logical consistency

7 = Casualty

8 = Mathematical Modeling

9 = Concept constructing

$10=$ Abstraction 
The average score of generic science skills at high school students are presented in Table II below.

\begin{tabular}{|c|c|}
\hline $\begin{array}{l}\text { Indicator of Generic Science } \\
\text { Skills }\end{array}$ & Score (\%) \\
\hline Direct Observation & $\begin{array}{l}76.62 \\
79.33\end{array}$ \\
\hline Scale awareness & 69.59 \\
\hline Symbolic language & 72.29 \\
\hline Logical framework & 27.81 \\
\hline Logical consistency & 18.72 \\
\hline Casualty & 41.88 \\
\hline Mathematical modeling & 46.32 \\
\hline Concept constructing & 43.94 \\
\hline Abstraction & 57.79 \\
\hline Average Score & 53.43 \\
\hline
\end{tabular}

Based on the Figure 1 and Table II, it can be seen that the highest scores of generic science skills at high school students are obtained by indirect observation with a score of $79.33 \%$; then the score of direct observation indicator is $76.62 \%$; a score of $72.29 \%$ is obtained by a symbolic language indicator; furthermore the scale awareness indicator scored 69.59\%; an abstraction indicator get a score of 57.79\%; then the score of $46.32 \%$ is obtained by the mathematical modeling indicator; next the concept instruction indicator get a score of $43.94 \%$; a score of $27.81 \%$ got by logical framework indicator; and the last logical consistency indicator got the lowest score of $18.72 \%$.

\section{DISCUSSION}

The generic science skills' indicator that gets the highest score is indirect observation and then direct observation. This is because in conducting indirect observation, students do not need many senses must be involved to obtain and collect data. The interview result from teacher telling that science learning in State Madrasah Aliyah 1 Surakarta has not run well. Not many experiment done in classroom when teacher teach the science learning due to the less time to do. It makes direct observation's student is not better that indirect observation.

Furthermore symbolic language and scale awareness' indicators get a pretty good score. Piaget's cognitive development theory is closely related to the object of the $11^{\text {th }}$ grades students of State Madrasah Aliyah 1 Surakarta as a sample. The $11^{\text {th }}$ grades students are in the formal operational phase. In the formal operational phase, characteristic such as abstract thinking ability, logical reasoning, drawing conclusions and information are available [16]. Students of $11^{\text {th }}$ grades in State 
Madrasah Aliyah 1 Surakarta can understand the learning materials with complex and abstract characteristics and many experiments within it.

The indicator of abstraction is intended to find out how far students can describe or analogy abstract concepts and events into the form of daily life through the stimulations in the module and train students to make visual animations of abstract microscopic events. This is in accordance with the age of students who are in the formal operational phase, so that they do not experience difficulties in this indicator. The indicator of mathematical modeling gets the low score. Students have not accustomed to make the formulation of the problem in the form of a specific question becomes one of the factors causing low scores on mathematical modeling indicators.

The causality, logical framework, and logical consistency indicators scored very low. The ability to think logical consistency requires a high level thinking [15]. This is because to create a logical consistency, logical framework, and states the existence of causal relationships, students are required to be able to connect between concepts and experimental data on the material that is being studied with the concept and data of experimental results of materials on the material that has been studied, then synthesizes it into a form of regularity of a particular pattern. The generic science skills are very important to build high level personalities and thinking patterns [10]. This is because the generic skills of science as a basis in the process of thinking high level that includes the ability to think creatively, critically, decision making and solving problems of the daily life.

\section{CONCLUSION}

The result of this study revealed that the generic science skills of high school students in State Madrasah Aliyah 1 Surakarta are still low. The average score is $53.43 \%$ which interpreted as a moderate score with indirect observation's indicator gets the highest score and logical consistency's indicator gets the lowest score. Generic science skills must be concerned by the practitioners. They should train students these skills through science subjects in the schools.

\section{ACKNOWLEDGMENTS}

Researcher would like to thank to all those who have helped this study research in especially to the students of State Madrasah Aliyah 1 Surakarta.

\section{REFERENCES}

[1] OECD. (2016). Pisa 2015; PISA Results in Focus. Retrieved from www.oecd.org/pisa/pisa2015-results-in-focus.pdf. 
[2] ACPD. (2017). Pusat Penilaian Pendidikan; Badan Penelitian dan Pengembangan; Mengenai TIMSS. Retrieved from https://www.acdp-indonesia.org/wpcontent/uploads/2017/01/TIMSS-infographic.pdf.

[3] Febriyanti, D., Ilyas, S., \& Nurmaliyah, C. (2014). Peningkatan Keterampilan Generik Sains Melalui Penerapan Model SSCS (Search, Solve, Create and Share) pada Materi Mengklasifikasikan Makhluk Hidup di MTSN Model Banda Aceh. Jurnal Biologi Edukasi Edisi 13, 6 (2), 43-47.

[4] Tawil, M. \& Liliasari. (2014). Keterampilan-keterampilan Sains dan Implementasinya dalam Pembelajaran IPA. Makassar: Badan Penerbit Universitas Negeri Makassar.

[5] Eaton, D. M., \& Whittle, S. (2012). Generic Skills in Medical Education: Developing the Tools for Successful Lifelong Learning. Medical Education, 46, 120-128. https://doi.org/10.1111/j.1365-2923.2011.04065.x

[6] Agustina, S., \& Muslim, M. (2012). Analisis Keterampilan Generik Sains Siswa pada Praktikum Besaran dan Pengukuran Kelas X di SMA Muhammadiyah 1 Palembang. Jurnal Inovasi dan Pembelajaran Fisika, ISSN 2335-7109, 1-7.

[7] Maknun, J. (2015). The Implementation of Generative Learning Model on Physics Lesson to Increase Mastery Concepts and Generic Science Skills of Vocational Students. American Journal of Educational Research, Vol. 3, No. 6, 742-748.

[8] NRC. (2008). Research on Future Skill Demands: A Workshop Summary. (M. Hilton, Ed.). Washington DC: The National Academies Press. https://doi.org/10.17226/12066.

[9] Geraei, E., \& Heidari, G. (2015). Measurement of Generic Core Competencies among Students of Library and Information Science in Iran. The Electronic Library, 33 (6), 10161030. https://doi.org/10.1108/EL-08-2013-0153.

[10] Rizal, H. P., \& Danial, M. (2013). Pengaruh Model Pembelajaran Inkuiri terhadap Keterampilan Generik Sains Siswa Kelas XI IPA SMA Negeri 1 Pangkajene Sidrap. FMIPA Universitas Negeri Makassar.

[11] Badcock, P. B. T., Pattison, P. E. \& Harris, K. L. (2010). Developing Generic Skills through University Study: a Study of Arts, Science and Engineering in Australia. High Educ, 60, 441-458. https://doi.org/10.1007/s10734-010-9308-8.

[12] Osman, K., Hamid, S. H. A., \& Hassan, A. (2009). Standard Setting: Inserting Domain of the 21st Century Thinking Skills into the Existing Science Curriculum in Malaysia. Procedia Social and Behavioral Sciences 1, 1, 2573-2577. https://doi.org/10.1016/j.sbspro.2009.01.454

[13] Zainal, K., Hassan, W. Z., \& Alias, J. (2012). Generic Skill Level of UKM Students after Pursuing the Compulsory General Studies Courses. Procedia - Social and Behavioral Sciences, 59, 558-564. https://doi.org/10.1016/j.sbspro.2012.09.314.

[14] Brotosiswoyo, B. S. (2000). Hakekat Pembelajaran Fisika di Perguruan Tinggi. Jakarta: Proyek Pengembangan Universitas Terbuka. Depdiknas.

[15] Sudarmin. (2011). Model Pembelajaran Kimia Organik Terintegrasi dengan Kemampuan Generik Sains. Jurnal Ilmu Pendidikan, 17 (6), 494-504.

[16] Ibda, F. (2015). Perkembangan Kognitif: Teori Jean Piaget. Intelektualita, 3 (3), 27-38. 